
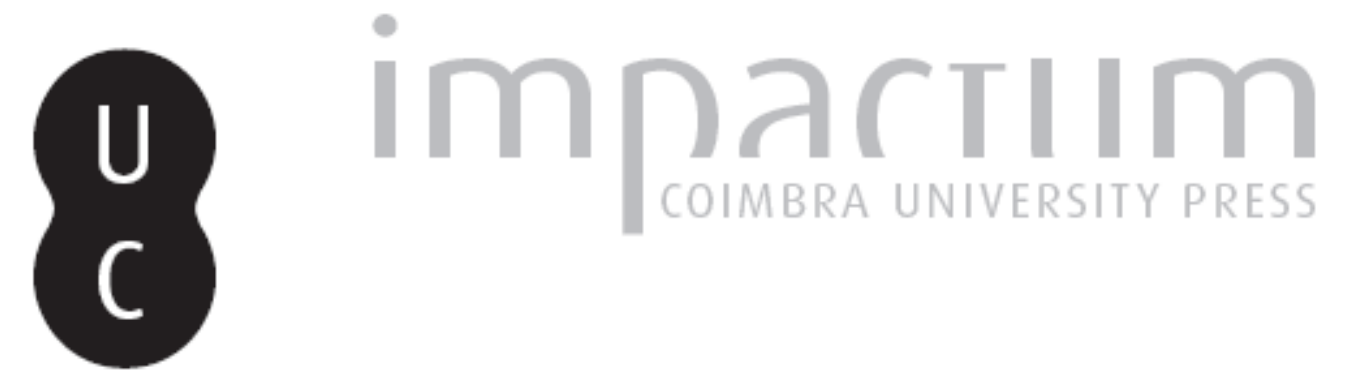

\title{
As cores do círculo de artes plásticas: a ambiguidade como ideologia
}

\section{Autor(es): $\quad$ Olaio, A.}

Publicado por: Imprensa da Universidade de Coimbra

URL persistente: URI:http://hdl.handle.net/10316.2/35453

DOI: DOI:http://dx.doi.org/10.14195/0870-4112_11_1

Accessed : $\quad$ 26-Apr-2023 13:48:16

A navegação consulta e descarregamento dos títulos inseridos nas Bibliotecas Digitais UC Digitalis, UC Pombalina e UC Impactum, pressupõem a aceitação plena e sem reservas dos Termos e Condições de Uso destas Bibliotecas Digitais, disponíveis em https://digitalis.uc.pt/pt-pt/termos.

Conforme exposto nos referidos Termos e Condições de Uso, o descarregamento de títulos de acesso restrito requer uma licença válida de autorização devendo o utilizador aceder ao(s) documento(s) a partir de um endereço de IP da instituição detentora da supramencionada licença.

Ao utilizador é apenas permitido o descarregamento para uso pessoal, pelo que o emprego do(s) título(s) descarregado(s) para outro fim, designadamente comercial, carece de autorização do respetivo autor ou editor da obra.

Na medida em que todas as obras da UC Digitalis se encontram protegidas pelo Código do Direito de Autor e Direitos Conexos e demais legislação aplicável, toda a cópia, parcial ou total, deste documento, nos casos em que é legalmente admitida, deverá conter ou fazer-se acompanhar por este aviso.

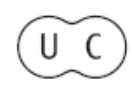




\section{ESTÉTICA E POLÍTICA}

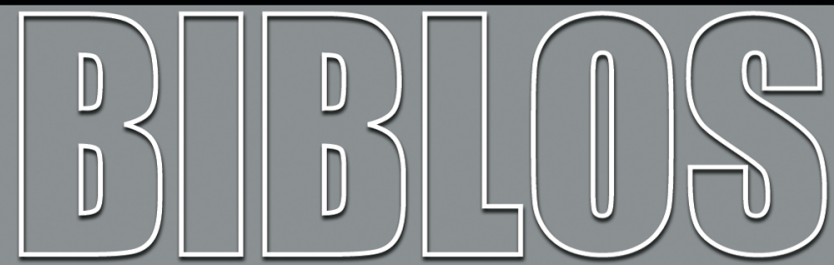

REVISTA DA FACULDADE DE LETRAS UNIVERSIDADE DE COIMBRA 
Biblos, n. s. XI (2013) 15-38

DOI: http://dx.doi.org/10.14195/0870-4112_11_1

A. Olaio

Departamento de Arquitetura da UC

\title{
AS CORES DO CÍRCULO DE ARTES PLÁSTICAS A ambiguidade como ideologia
}

\section{Resumo}

\section{A AMBIGUIDADE COMO IDEOLOGIA}

A Semana da Arte na Rua na génese do grupo CORES, e a partir daí.

Nos primeiros anos da revolução de Abril, as experiências dos artistas do Círculo de Artes Plásticas de Coimbra, e o seu eco nos artistas portugueses actuais, é um estimulante ponto de partida para reflectir sobre o lugar da ambiguidade na arte e as suas relações com a vida urbana.

Palavras chave: Arte Contemporânea, Arte Pública, Arte Conceptual.

\begin{abstract}
Ambiguity as Ideology

The "Week of art in the street" in the genesis of group COLOURS and thereafter.

Looking back to the early years of Portuguese revolution, to the experiences of the artists of Círculo de Artes Plásticas de Coimbra in those days, and its echo in contemporary Portuguese artists, we find a challenging starting point to reflect on the place of ambiguity in art and its relations urban life.
\end{abstract}

Keywords: Contemporary Art, Performance, Conceptual Art. 


\section{Armando Azevedo: cor e conceptualismo}

- Viva o vermelho! - grita Armando Azevedo em Almada, no Verão de 1983.

Bandeira vermelha, olhos vendados com venda vermelha, transeuntes atónitos perante a bizarria da situação, apanhados desprevenidos numa performance que acontece sem se anunciar, nas potencialidades perturbadoras do happening.

Decorria então em Almada a Alternativa II, Festival Internacional de Performance.

A afirmação de uma cor, assim, sobretudo tratando-se do vermelho, sublinha a conotação ideológica, autonomizando simultaneamente o vermelho de todas as ideologias, evidenciando esta cor a sua condição polissémica, ao mesmo tempo que se afirma para além de toda a polissemia.

Nesta performance de rua, Armando Azevedo beijava tudo o que lhe chamasse a atenção pelo mero facto de ser vermelho, não recusando a própria sujeição à humilhação, quando aceita beijar os sapatos vermelhos de uma rapariga que, provocatória, quer testar a convicção do artista. E segue pelas ruas de Almada cumprindo esta missão, enquanto Manuela Fortuna vai atirando, gentilmente, pétalas vermelhas sobre ele, assumindo-se como personagem que age sobre a acção, intervenção exterior à acção, mas que a sublinha, como que marcando a sua dimensão estética, mas também o seu sentido ritualístico, nesta procissão de um só indivíduo.

Nesse dia, o almoço de Armando Azevedo também foi vermelho ou, melhor, ele tornou-o vermelho, pintando com corante tudo o que iria ingerir. No refeitório onde os artistas se reuniam para almoçar, intervalo num dia de performances, este artista persistia em manter ali a sua condição de performer, acentuando a forma obsessiva como traduzia ali a relação com uma cor.

No mesmo ano, no festival inaugural do Espaço Lusitano, no Porto, Armando Azevedo usa uma venda azul e assume a obsessão do azul. A cor oficial da cidade do Porto não é o azul, mas o azul é a cor em que pensamos quando pensamos no Porto, porque é a cor do Futebol Clube do Porto.

$\mathrm{Na}$ performance que fez no pequeno espaço do Espaço Lusitano, Armando Azevedo pinta uma galinha de azul e mata-a, afirmando que o sangue é azul. Mas o sangue resiste a ser azul e corre vermelho. De 
certa forma, ficam evidentes os limites da arte conceptual. O sangue não passa a azul por ser nomeado como tal. O nominalismo pictural tem os seus limites... O Padre Antonio Vieira refere que o milagre do Milagre das Rosas não terá sido propriamente a transformação do pão em rosas, mas sim o facto da Rainha Santa Isabel ter dito que eram rosas e serem-no. Foi o acto de nomear que as terá tornado rosas.

Se considerarmos que Armando Azevedo não faz milagres, a persistência do vermelho do sangue quando se afirma de forma tão veemente que ele será azul, por si só, já é uma fortíssima experiência estética, sublinhando a força desta cor na própria relação entre o sangue e a morte. Se acreditarmos que Armando Azevedo faz mesmo milagres, aquele sangue passará mesmo a ser azul, mesmo que os olhos nos continuem a dizer que é vermelho, ganhando a consciência de que a cor afinal será sobretudo uma entidade conceptual, para além de toda a visualidade. Assim, este azul do sangue, seria um azul que aos olhos surgiria como vermelho, mas que de facto era azul, numa constatação dos limites da percepção humana.

Ainda hoje, nas performances de Armando Azevedo, a cor aparece nas suas potencialidades conceptuais. Ao mesmo tempo que aproxima a performance do campo da pintura, aproxima a pintura da performance. Como na performance que fez no festival de performance Line_Up Action em Coimbra em 2011 (no contexto da série de performances que tiveram lugar nos espaços do Círculo de Artes Plásticas de Coimbra do Jardim da Sereia) onde explorava as ambiguidades geradas na relação entre o nome das coisas e o nome da sua cor, a cinza que é cinza, a laranja que é laranja e sabe a laranja (a cor ou o fruto?), ou quando a cor das coisas dependia da forma como eram encaradas. Performance que termina quando acaba de pintar uma melancia. Primeiro de verde, porque é assim que a vemos, em seguida, de vermelho, depois de constatar que a cor do seu interior afinal não corresponde à cor exterior. E, na sobreposição da tinta vermelha sobre a tinta verde ainda fresca, o resultado é uma cor pardacenta na anulação mútua do verde e do vermelho.

Tudo o que a performance, na sua origem, quereria recusar, no afastamento da obra pictórica, para a efemeridade de um acontecimento significante, é aqui convocado, explorando por vezes a própria pintura enquanto processo. $\mathrm{E}$, sobretudo, a cor que não nega a sua plasticidade, ampliando ao mesmo tempo essa condição a todas as potencialidades conceptuais. 
Aproximando a forma do conceptual, celebra também a plasticidade dos conceitos. Pintura e performance sem descontinuidades, afirmando uma essencialidade comum.

\section{A "Semana da Arte na Rua"}

De certa forma, este performer, na assunção do artista enquanto personagem, carrega em si também a nostalgia de outros tempos. Armando Azevedo surge como resistente de um projecto que começou por ser um projecto colectivo que nasceu na Semana da Arte na Rua em Coimbra, em 1976. E acabou em 1978, numa reunião final onde só Armando Azevedo esteve presente e da qual resulta uma acta só assinada por ele, sobre as marcas de dez impressões digitais, impressões dos dedos das suas mãos. Terminou assim o "grupo CORES", no paradoxo de uma reunião singular em todos os sentidos.

O Grupo de Intervenção do Círculo de Artes Plásticas (de Coimbra), mais tarde conhecido por "grupo CORES nascendo quando aconteceu a Semana da Arte na Rua, surgiu na transformação em acto performativo do que poderia não passar da experimentação nos ateliês do CAPC.

$\mathrm{Na}$ altura, Armando Azevedo era professor e coordenador de actividades artísticas no Círculo de Artes Plásticas de Coimbra. E é no CAPC que propõe aos seus colegas de ateliê um projecto que parte da pintura para a roupa. Aqui roupa como algo de pessoal e intransmissível. Cada um cria a sua própria pintura que depois vestirá.

Cada um partirá da mesma porção de tecido, um corte de pano-cru sobre o qual fará a pintura que quiser, sabendo depois que a irá vestir. Uma pintura que se veste, pintura tornada corpo, ou que se moverá pela acção do corpo. Pintura e performance. Pintura/performance, aqui não propriamente como a performance do acto de pintar, não da pintura enquanto processo mas sim a partir da pintura enquanto resultado, o resultado da pintura como agente da acção, e também como sendo a pintura o que envolve a acção, pele da própria acção. Ao mesmo tempo, levando a pintura para o espaço urbano, vestindo-a para sair à rua, sublinha-se a urbanidade da própria pintura, como se a pintura se encontrasse no lugar que lhe é próprio. Na relação entre o artista e os outros, na vocação comunicativa da pintura, a pintura pertence tanto ao ateliê quanto à rua. 


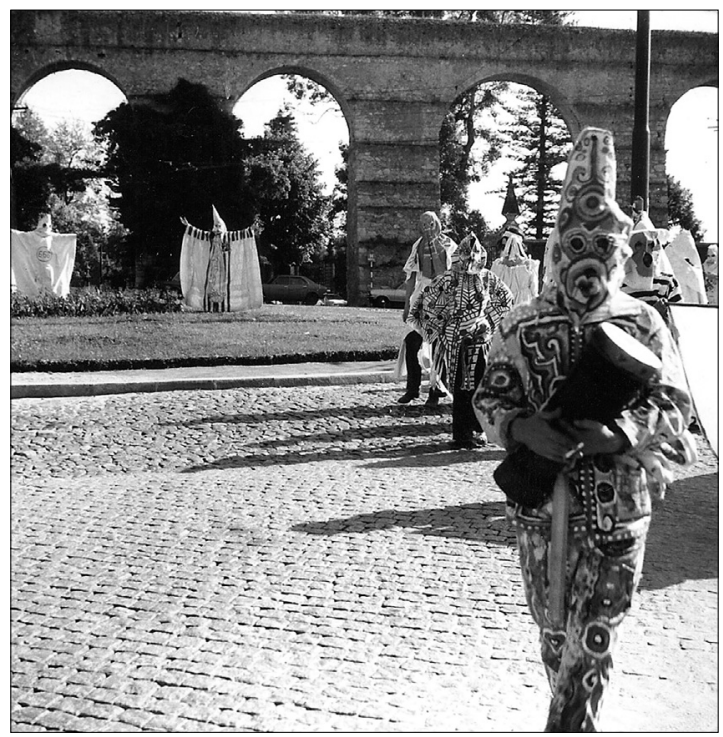

GICAP na "Semana da Arte na Rua”, Coimbra, 1976.

(C) Círculo de Artes Plásticas de Coimbra

A Semana da Arte na Rua, projecto do CAPC que tem a Praça da República como centro principal na sua intervenção no espaço urbano da cidade de Coimbra, acontece no mesmo ano das primeiras eleições livres, período de celebração da Liberdade, na euforia dos primeiros anos da Revolução dos Cravos.

Desde logo, uma revolução em que as flores parecem tomar o lugar das armas, ou que se afirmam como armas, evidencia uma dimensão estética única, sobretudo no contexto das revoluções.

Eesta Semana da Arte na Rua apela à participação de todos. Nasce das artes plásticas para chamar, desde bandas de música a concertos como o dos Anarband de Jorge Lima Barreto e Rui Reininho, teatro amador, ... numa atitude inclusiva que acaba por nem o artesanato deixar de fora. Aqui não propriamente para um nivelamento acrítico mas sim numa atitude festiva que, ao mesmo tempo, aposta sobretudo nas relações que se estabelecem na experiência de uma simultaneidade de atitudes.

Todas estas participações são sobretudo agentes de uma ideia performática total que é esta Semana da Arte na Rua e, desta forma, o 
sentido performativo das artes plásticas assume aqui, visivelmente, a sua dimensão urbana.

Terá sido na exploração da complexidade da dimensão urbana da arte, ou da arte enquanto reflexão sobre a vida, que a Praça da República se transforma num grande labirinto. Aqui, o espaço de liberdade associa-se à ideia de labirinto não propriamente como jogo de contrários, mas sobretudo pelas potencialidades conceptuais desta relação, naquilo que poderá ter de eloquente e perturbador no que diz respeito aos espaços de liberdade ou às complexidades da condição urbana.

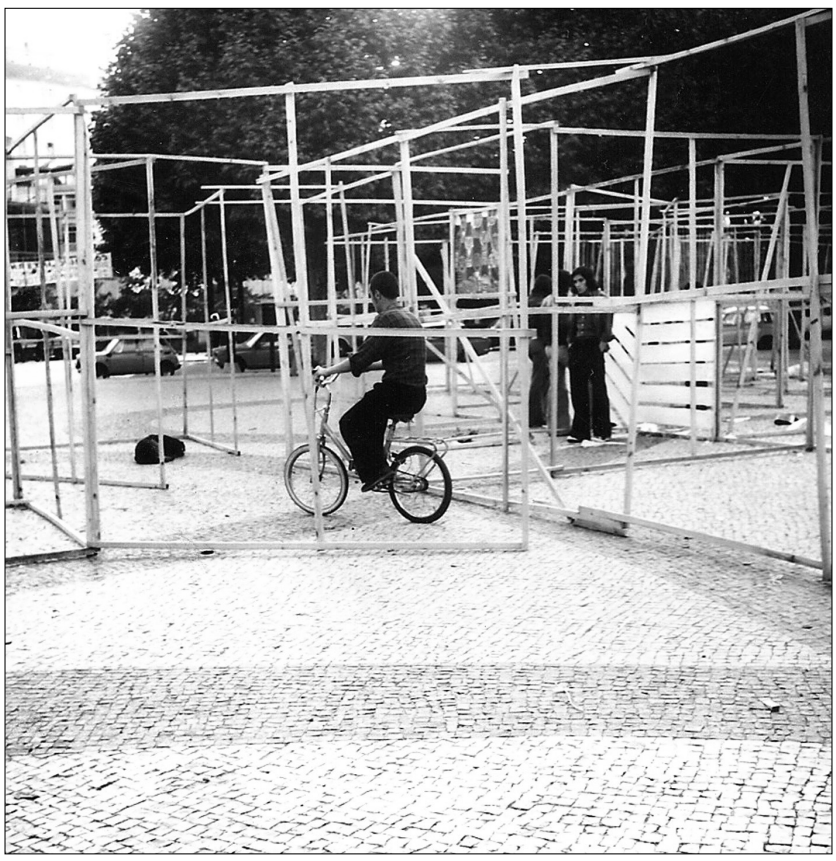

“Labirinto”, Semana da Arte na Rua, Coimbra, 1976.

(C) Círculo de Artes Plásticas de Coimbra

Neste labirinto, uma estrutura feita de ripas de madeira, transparente, criando percursos e ao mesmo tempo condicionadora de percursos, quem respondesse ao repto e quisesse participar, poderia ocupar um lugar. O que traduzia este apelo à participação e o assumir a posse do 
espaço urbano pelos cidadãos, mas, ao mesmo tempo, cada pessoa que se apoderasse de uma porção deste espaço o bloquearia parcialmente, diminuindo as possibilidades dos seus percursos (espaço para mostrar o produto da sua criatividade, como as suas pinturas ou, mesmo, os seus tapetes de arraiolos).

Nesta passagem do ateliê para a rua, sobretudo neste contexto galvanizador desta Semana da Arte na Rua, este nascimento do Grupo de Intervenção do Círculo de Artes Plásticas evidencia a sua matriz urbana e a forma como encara o espaço como espaço de intervenção.

Para o GICAP, o espaço é espaço de intervenção, e a forma como virão a encarar a sua relação com as cores nasce da consciência de um contexto fortemente politizado, numa época em que as pessoas descobriram que as ideologias já se poderiam afirmar sem constrangimentos.

\section{As cores do "Grupo CORES"}

O Grupo de Intervenção do CAPC é de facto dos mais fortes protagonistas da história heróica do CAPC dos 70's. A sua atitude performativa leva-o a ser mais conhecido por "grupo CORES", sobretudo a partir de acções como a que realizaram representando o Círculo de Artes Plásticas de Coimbra na Alternativa Zero, organizada em Lisboa por Ernesto de Sousa, em 1977. Aí cada um envergava uma vestimenta monocromática. "O todo e a parte; a parte e o todo" era o título da sua acção. Na expansão do pictórico para a acção performativa, cada um, cada cor, cada parte, se assumia como sendo o todo. Defendia cada um a sua cor como quem defende uma ideologia e, radicalmente, como se fosse a única.

Foi nesta condição que entraram na galeria de Belém, espaço da Alternativa Zero, juntos, mas distintos pela monocromia das vestes. Encapuçados, com capas que tapavam a cabeça, deixando buracos para a boca e os olhos, apertadas no pescoço e na cintura, colar e cinto da mesma cor, em versões monocromáticas da tela/roupa que nasceu na sua presença na Semana da Arte na Rua.

Armando Azevedo assumia o azul, Túlia Saldanha, o preto, António Barros, o vermelho, Rui Órfão, o verde, Ção Pestana, o laranja, Teresa Loff, o amarelo, Alfredo Pinheiro Marques, o branco, (Manuela Fortuna que integrou o grupo numa fase posterior viria a assumir o 
violeta). E colocados em círculo no centro da galeria, cada um procura captar o público para a sua cor como se de uma causa se tratasse. Em acções simultâneas, cada um propagandeava a sua cor. “... fazendo, durante longo tempo e dos mais diversos modos e modas, a propaganda do, por exemplo, azul, escrevendo azul, louvando o azul, gritando azul, bebendo deliciadamente azul , (...), ostentando um espelho azul, reflectindo as pessoas em azul, num sorriso azul..."

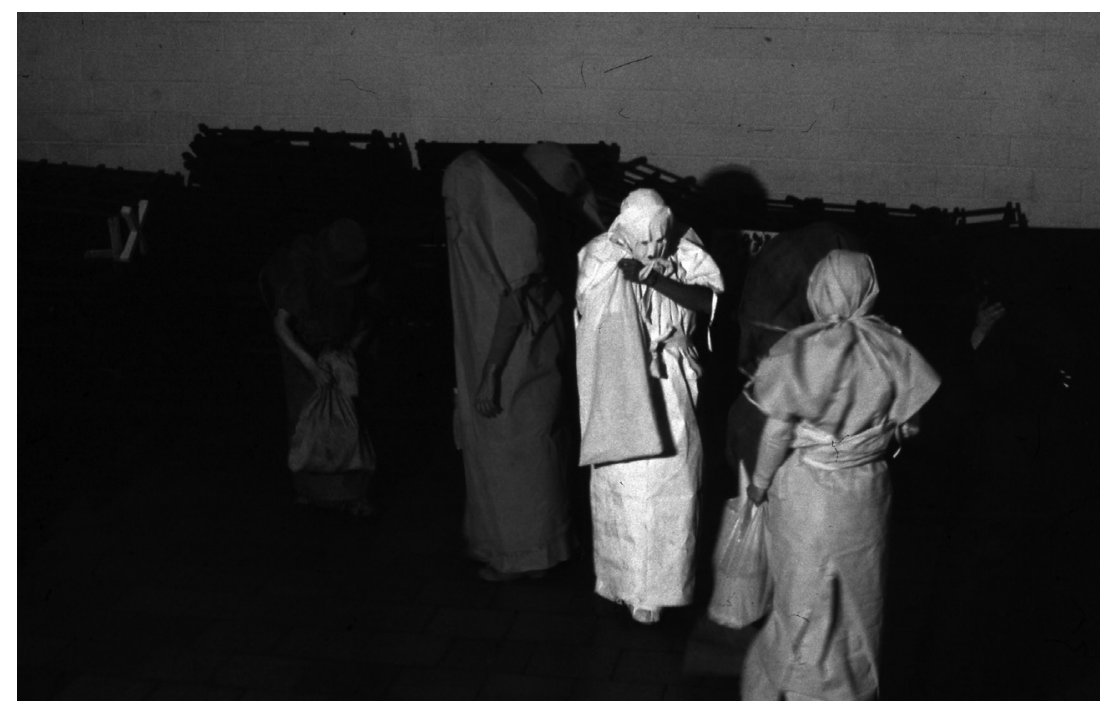

Grupo CORES na “Alternativa Zero", Lisboa, 1977.

(C) Centro de Estudos Multidisciplinares Ernesto de Sousa

Em 1972, para a primeira exposição que faz no CAPC, e sua primeira exposição individual, Armando Azevedo recolhe do lixo embalagens de diversos tipos e de diferentes formas e pinta-as de branco. As paredes negras da recente sala de exposições da casa da Rua Castro Matoso acentuam a brancura imaculada destes objectos.

As salas da casa do CAPC funcionavam como ateliês ou salas de aula, mas em 1969 a dinâmica dos artistas que os frequentavam leva ao desejo de criar um lugar para apresentação das suas práticas e, no que teria sido uma sala de aula, nasce assim a galeria negra. Aqui o negro é certamente uma cor, mas também resulta como uma forma de 
atenuar a ortogonalidade daquele espaço, paredes de uma invisibilidade nocturna, expandindo-o à aparência de uma espacialidade sem limites.

Brancas, luminosas, naquele espaço negro, as embalagens que Armando Azevedo expõe assumem um protagonismo que as resgata do lixo de onde vieram. Brancas, imaculadas, já não serão certamente lixo. Sendo obras de arte, ainda menos lixo serão. Estas embalagens assumem uma virgindade nunca anteriormente encontrada, ao retomarem a condição de pura possibilidade, como uma tela branca. Sendo embalagens, na procura de sentido quando estamos perante uma obra de arte (onde muitas vezes o fascínio reside sobretudo no processo da procura de sentido), são conteúdos que são continentes. Ou seja, o seu conteúdo conceptual reside na sua condição de embalagens, na sua condição de continentes. O seu fim maior é a sua condição de embalagens, não o que contém, como se imaginássemos um Natal em que se guardaria o embrulho das prendas mais do que o que elas continham. E, de facto, as prendas começam por ser o embrulho, perdendo toda a visualidade que as caracteriza como prendas, assim que o embrulho é aberto.

Estes objectos pintados de branco, sobretudo tratando-se de embalagens, abrem dois caminhos possíveis na obra de Armando Azevedo que darão origem aos objectos cobertos com colagens de referências diversas (como a série de cadeiras cobertas de emblemas de partidos políticos, ou de imagens de santos, ou de imagens eróticas, ou de imagens de fotonovelas) ou à ideia daquele branco na sua condição de cor onde outras cores poderiam estar, ou, melhor, de superfície que poderia ser pintada de qualquer cor, inclusivamente de branco. A monocromia iniciática do branco daquelas embalagens certamente terá dado origem à exploração do conceptualismo das cores no trabalho sequente de Armando Azevedo.

Nas suas performances, a monocromia assume-se como monomania, mas uma monomania explosiva, trabalhando obsessivamente cada cor, mas explorando a infinidade de relações conceptuais que a partir de cada cor se podem estabelecer.

As performances do "grupo CORES" (utilizando aqui intencionalmente o nome com que o GICAP era mais conhecido) davam a cada cor uma voz, sendo os ecos de cada cor fruto da visão de cada um dos artistas do grupo. Como o azul para Armando Azevedo começava por ser azul esferográfica (instrumento privilegiado na sua pintura). Ou, como testemunha António Barros: 
“... Coube-me sim, neste jogo (da "Glória” sem glória) uma condição: a de receber o espaço da cor socialmente em devir no cenário de um tempo de transformação - o lugar do vermelho (cor tão fortemente simbólica e comprometida com o querer (e os seus contrários), nesses nervosos e já longínquos anos setenta (que foram em Portugal "teatro de quase guerra" da Revolução de Abril, sempre tão convulsiva na busca de uma identidade, aí também cromática)."

A expressão "qual é a tua cor?" caiu quase completamente em desuso, tanto quanto o interesse de o perguntar. Nos primeiros anos pós-revolução, a relação entre cor e ideologia tinha uma forte presença. Raramente se usaria uma cor sem ponderar na possibilidade de uma mensagem política só pelo facto de a usar.

Em 1977, três artistas do CAPC criam obras para uma "Homenagem ao 25 de Abril". A "Ventoínha" de Ção Pestana, uma bandeira portuguesa de papel transformada em moinho de vento, fazendo assim o símbolo da nacionalidade rodar, festivamente celebra a acção, a liberdade de agir. António Barros cria uma desconcertante "Cadeira-de-rodas" que, de facto, era uma cadeira com rodas. Uma banal cadeira de madeira onde cada perna terminava numa forma circular como uma roda. Obra assumidamente escultórica como os monumentos costumam ser, elevada sobre um plinto, e tudo coberto por uma argamassa unificadora como que se tudo fosse feito da mesma matéria. Cadeira com rodas, cadeira que anda, numa apologia do dinamismo. Cadeira-de-rodas, assombrada pela sugestão de um corpo paralisado, que não se consegue mover pelos seus próprios meios. Imagem fortemente perturbadora no contexto desta homenagem. Oscilando entre a ideia de liberdade e o seu contrário. Provocatória e revolucionária no apelo a uma lucidez inconformista.

Armando Azevedo apresenta "Redoma", onde, sobre um cubo de pano-cru esticado como poderia estar na grade de uma tela, outro cubo de dimensões idênticas, cada face de tecido transparente de cor diferente. Dentro desse cubo, outro cubo menor, tendo em cada face uma cópia da primeira página de um jornal do dia 25 de Abril de 1974, colorida da mesma cor da face correspondente do cubo exterior.

Nessa primeira página está uma fotografia do próprio Armando Azevedo, com farda militar, lendo a primeira edição desse mesmo jornal. Extraordinária coincidência do artista que encontra a sua própria imagem como imagem marcando o dia da Revolução. E um jornal que esgota e que, numa segunda edição, se reproduz a si próprio nas mãos 
daquele militar, como se quisesse sublinhar que o que aconteceu, aconteceu mesmo, até porque saiu no jornal.

E tudo isto, só 3 anos passados, já numa redoma. Mas naquela "Redoma", que associa a expectativa sacralizadora de uma redoma com aquele objecto que mais parece um banal mosquiteiro com as suas faces. Mas um mosquiteiro policromado e que conserva o documento tão precioso, sobretudo por conter em si esta incrível simultaneidade de referências, na genialidade de jogos conceptuais que só a realidade consegue produzir, assim, como se o acaso existisse.

\section{Exposição MONO (monocromia e polissemia)}

Explorando as potencialidades polissémicas da cor, em 2010, a par de uma evocação do "grupo CORES" e da sua história, que foi feita no Círculo de Artes Plásticas, colaborei na organização de uma exposição para a qual convidámos mais de seis dezenas de artistas. Desde logo, MONO, título da exposição, se parecia afirmar por contraste com a quantidade de artistas e, consequentemente, com a forma exponencial das relações conceptuais despoletadas pelo confronto das suas múltiplas visões.

Por outro lado, os artistas foram convidados a exporem obras que partissem do conceito de monocromia, não obrigatoriamente, monocromias. Sendo assim, enviaram obras onde, frequentemente, uma monocromia não responderia às relações que ali poderiam ser estabelecidas.

Albuquerque Mendes envia uma pequena tela com grade de grande espessura. Cada face do objecto/tela barrada a espátula com tinta espessa de uma cor diferente, uma monocromia em cada face. Ao mesmo tempo esta pintura/objecto, da forma como a massa de tinta era colocada nas suas superfícies, parecia procurar a aparência de um bolo. A cor como coisa como as coisas comestíveis? A pintura, mais do que representação bidimensional, na simultaneidade de diferentes planos, adquiria as qualidades miméticas da escultura.

Alice Geirinhas apresenta um pequeno desenho cuja larga moldura dourada contrasta com a elementaridade gráfica das representações de 12 soldados, como que módulos de um padrão, parecendo ser clones de um mesmo indivíduo preenchendo o rectângulo do suporte (defenderão a mesma cor?). 
Ana Pérez-Quiroga expõe vários quadrados de tecidos de várias cores sobrepostos, agarrados numa barra de madeira, como poderiam estar numa loja como amostras de tecidos. Aqui a pintura é evocada, transpondo a paleta para outros contextos, nas potencialidades dos tecidos poderem ser roupa, usados no corpo, ou na decoração do espaço doméstico, serem cortinas, colchas, toalhas. Paleta que nos mostra possibilidades alternativas e em múltiplas combinações de colorir os nossos espaços.

Ana Rito mostra uma fotografia de uma mulher (em roupa interior?) sensualmente reclinada nos degraus de umas escadas, o corpo quase totalmente escondido na sombra. E é a sombra que dá o título à fotografia. "One black shadow" traduz o descentrar da atenção da personagem para a sombra que a cobre. Será certamente o negro da sombra que a esconde mas, ao mesmo tempo, é ele que revela a sua sensualidade.

António Melo apresenta uma pequena paisagem. Pintura na tradição oficinal do óleo sobre tela, onde o título "Verde" tem uma relação óbvia com as árvores representadas, mas que é contrariado pela própria realidade cromática da paisagem figurada. Paisagem de inverno, onde os cinzentos prevalecem.

António Olaio mostra um vídeo da canção "Blaupunkt blues" (escrita com o músico João Taborda). Na exploração da forma exponencial como os conceitos se poderão relacionar, estes "blues", serão azuis mas também serão "blues" como as canções. Serão imagens de outra ordem ao serem marca de televisores e electrodomésticos, enquanto "Blaupunkt blues". Mas também, como a letra da canção mostra, serão azuis que poderão traduzir outras cores, ou por elas serem traduzidos, em multiplicação sinestésica: “... I want a blue that looks like red. I want a blue that sounds like yellow".

António de Sousa, sobre uma página com o poema "Povo" de Pedro Homem de Melo, risca com caneta azul, criando um rectângulo monocromático que tapa o poema tornando quase impossível a leitura, mas continuando a revelar a presença da mancha gráfica do texto. Só a referência ao poeta e o título "Povo" não estão cobertos. E a palavra "Povo" fica assim pairando sobre o poema escondido em azul que, assim, parece que a define, como se "Povo" fosse a legenda daquele rectângulo azul que esconde o poema. Os limites claros do rectângulo azul evocarão certamente a elementaridade da estética minimalista, contrastando com a organicidade do preenchimento gestual que o humaniza. 
Arlindo Silva mostra um fragmento de uma memória, pormenor de um interior doméstico. Vasos, garrafas, sabão. Objectos sobre um tanque de lavar roupa. Fragmento visual que, na sua intimidade, conseguirá evocar uma realidade que não voltará, num desenho cinzento como as memórias.

Armando Azevedo associa a monocromia à hegemonia de uma identidade, criando uma pintura/objecto onde a própria moldura é suporte, escrevendo a sua assinatura, repetidamente, sobre o papel que tudo cobre. A sua assinatura escrita a esferográfica azul ocupa toda a superfície do objecto, chegando-se a sobrepor e a adensar, até à ilegibilidade. Se o processo de escrever aquela assinatura continuasse, poderíamos esperar certamente que nada do papel branco restaria por cobrir. Mas a monocromia azul que resultaria não poderia deixar de ser fortemente marcada pelo processo com que teria sido feita, um azul resultado de uma identidade assim, obsessivamente, densificada, ou revelada na sua densidade intrínseca.

Armando Azevedo apresenta outra obra semelhante, mas cujo rectângulo interior da moldura está ocupado por pães de diferentes formas, também tudo coberto por papel. Tudo adquire, assim, moldura incluída, a qualidade de suporte. Mas aqui o que é escrito sobre toda a superfície é a frase "São rosas", insistentemente, como se a repetição do acto de nomear pudesse surtir o milagre.

Baltazar Torres mostra um pequeno rolo de fita-cola preta que se agarra à parede. E o preto desta fita-cola tem linhas brancas como uma estrada. É um preto alcatrão, uma estrada de alcatrão enrolada. Podendo potencialmente se desenrolar em várias direcções e percursos, riscando estradas na paisagem, procurando os caminhos mais curtos e velozes, contrariando a complexidade topográfica da paisagem.

Carlos Antunes expõe um curto pedaço de ramo afiado como uma estaca (ou como um lápis, ou uma caneta?). Há um pedaço deste objecto que se solta deixando ver um interior pintado de preto, como se esta estaca (lápis ou caneta) fosse contentora de tinta preta. Mas a peça que se solta é de chumbo que teve aquele pedaço de madeira como molde, conferindo ao objecto mais o carácter de escultura que de readymade. O título "A casa iluminada" parece contrastar com o sombrio daquele negro interior. Mas será de traços negros que as casas são desenhadas. De preferência, luminosamente. 
Carla Cruz, desconcertante, parece limitar-se a riscar um círculo amarelo numa folha A4. A lápis de cera, como nos desenhos que se fazem muitos antes de qualquer pretensão de arte. Mas, como o título indica, aquele círculo amarelo corresponderá a uma "Democracia Radical Pluralista". O título: "Estados: Democracia Radical Pluralista" faz crer que a aquele círculo amarelo corresponderá um tipo de Estado entre outros. Emblema ou o próprio Estado? Representação ou a própria coisa? Na possibilidade de que seja a própria coisa, aquele círculo amarelo será prova de que a arte seja um mundo paralelo com as suas próprias regras, na plasticidade dos jogos de conceitos no campo lexical da organização política ou de outras realidades.

Carlos Lobo mostra uma fotografia que tende para a monocromia, efeito do nevoeiro da própria paisagem fotografada, que elimina quase completamente os contrastes que ainda deixam adivinhar um monte, uma linha de praia e a água do que poderá ser o mar, um lago ou um rio. Densificando-se mais o nevoeiro, os elementos da paisagem deixar-se-iam de ver. No contexto conceptual desta exposição, poderemos vir a acreditar que quaisquer pinturas monocromáticas não poderão ser afinal mais do que representações de paisagens escondidas na densidade de nevoeiros cinzentos, brancos, ou então amarelos, vermelhos, azuis, verdes, ...

Carlos Pinheiro mostra um pequeno acrílico sobre papel, representação de um espaço interior, palco ortogonal como uma caixa, paredes, chão e tecto, contendo várias caixas, buraco como caixas escavadas no chão, e uma personagem sentada, reclinada, parecendo descansar do labor de colocar aquelas caixas como estão, ou preparando-se para continuar na organização daqueles paralelepípedos, escolhendo o lugar para as caixas coloridas, que se destacam na vivacidade da sua monocromia. Um mundo sempre em construção, na diversidade combinatória dos seus elementos.

Carlos Vidal expõe um texto, excerto de "Sociedade do espectáculo" de Guy Débord, recortado em cartolina preta, contrastando a fragilidade do material com a expressividade das letras recortadas, veementes na espessura das suas linhas. O texto ocupa todo o suporte, ou melhor, sendo nele recortado, coincide com o próprio suporte, pois é dele o material de que é feito. Suspenso numa moldura-caixa dourada mas de interior negro (e, por isso, de profundidade indeterminada) a folha de ouro que cobre a superfície da madeira que o emoldura confere- 
-lhe uma materialidade, um valor na materialidade que se acrescenta á importância do texto citado. Texto que, na quase ilegibilidade total, pela sua densidade e pela espessura das suas linhas, parece ser sobretudo evocação do texto do qual é excerto, mais do que se limitar a esta condição de fragmento. A monocromia que aqui se destaca será certamente a do dourado, cor espectáculo, representação do valor, visual e materialmente.

Catarina Saraiva, apresenta um objecto circular branco, ambíguo nas realidades que as suas qualidades escultóricas evocam., Abstracto na composição dos seus elementos, mas acolchoado como um sofá ou uma almofada. E o título diz-nos que é um espelho, multiplicando as associações conceptuais, na possibilidade de se tratar também de um lugar de projecção de subjectividades.

Cristina Mateus, pinta uma tela que resulta da justaposição de um quadrado branco sobre um quadrado preto, de um quadrado branco dentro de um quadrado preto, ou então num quadrado branco emoldurado a preto como o título parece indicar? Aqui o título "Pintura vazia" , conduz a leitura das formas, tornando-se aquele branco não uma cor mas um espaço vazio no interior da tela que, assim, não será mais lida na elementaridade de uma abstracção geométrica, mas sim como uma representação. Neste caso, a representação de um vazio.

Emanuel Brás expõe "O reservatório de mutações", uma fotografia que mostra um extenso terreno coberto de plástico, exploração agrícola sob aquele manto que, ao mesmo tempo que tudo uniformiza com branco da sua cor, esconde o mistério do produto do experimentalismo agrícola. Imagem enigmática e perturbadora, desde logo na forma violenta como se apodera da paisagem.

Fabrízio Matos expõe um animal, um pangolim, modelado em plasticina preta, colocado numa vitrina feita à sua medida, como poderia estar um animal embalsamado num museu de zoologia. Encontramos aqui a ideia de escultura sobretudo como reprodução mais do que representação. $\mathrm{O}$ artista não interpreta o modelo, reprodu-lo. Ou podemos pensar que o recria, assumindo um papel de criador ou recriador das espécies. E a opção monocromática evidencia o facto de se cingir às formas, modeladas com a matéria de que as coisas poderão ser feitas. E a plasticina tem esta propriedade de se manter dúctil. A mesma plasticina está pronta a ser usada para modelar outros animais, ou mesmo actualizar uma evolução desta espécie. 
Fernando José Pereira leva a monocromia a coincidir com a ideia de uma (quase) invisibilidade, ao expor uma fotografia de neve que cai, flocos de neve como pulsação quase invisível que cria espacialidade e transparência no que parecia ser uma superfície plana e opaca. "Freezing the snow falling" contraria a redundância aparente de congelar o que já será feito de cristais de gelo, porque é o movimento da queda da neve que aqui é congelado no instante fotográfico.

Fernando Ribeiro mostra um espelho de moldura luminosamente amarela, mas um espelho sem polimento que reflecte as coisas como vultos. O artista chama-lhe "sombra clara", fazendo coincidir a ideia de reflexo com a ideia de sombra, ou, melhor, criando um novo conceito que resulta da junção dos dois.

Francisco Cardoso Lima mostra-nos fotos da série "Stone". Em cada uma, uma pedra de granito. Sempre o mesmo material, nas variações da aproximação de cada pedra talhada à forma de um paralelepípedo. São as pequenas diferenças de forma que cada monólito assume e o enquadramento centrado com que são fotografadas que acaba por gerar a estranheza de uma aproximação ao retrato. No limite, até uma imagem antropomórfica poderia ser gerada. Formas de uma mesma espécie, pequenas variações fisionómicas.

Francisco Queirós mostra um trabalho sobre papel onde pinta um rectângulo com tinta branca translucida sobre manchas de transparências multicolores, deixando por cobrir só a silhueta de um pássaro. $\mathrm{Na}$ pintura está explícito o título "O meu pardal é um canário", transformação conceptual e cromática de uma silhueta de um animal para uma afirmação da ambiguidade da sua espécie.

Gabriela Vaz apresenta uma sequência de folhas brancas com texto em braille. Texto cuja plasticidade formal se apresenta na visualidade, mas cujo sentido só apreenderá sobretudo na invisualidade dos que se viram obrigados a aprender aquela escrita.

João Pedro Vale mostra-nos "White rainbow", uma bandeira feita de seis tiras de horizontais de pano branco cosidas. Transformação, numa monocromia, do arco-íris da bandeira do movimento gay. Aqui, uma monocromia branca, como a que poderia ser obtida pelo conjunto das cores. Mas em bandeira, como na luta por uma causa.

Jorge Colombo mostra uma moldura digital, inicialmente como monocromo negro mas onde se vão acendendo e apagando pequenos rectângulos coloridos num crescendo de luminosidade urbana na repre- 
sentação das janelas de arranha-céus que ocupam todo o enquadramento. E nesta janela, em grande densidade urbana, o número de luzes vai crescendo, voltando a decrescer até voltarmos á imagem muda do rectângulo preto inicial.

José Maçãs de Carvalho em "Iconofilia \#1" mostra-nos um plano estático sobre as árvores de um bosque onde sucessivamente vão surgindo, esvoaçantes, balões de várias cores em formato de coração. Ícones de ar que avançam pela paisagem indiferente. Imagens de forte conotação simbólica, formas de vida tão efémera quanto o sentido festivo que, paradoxalmente, transmitem.

O músico José Valente, respondendo ao contexto desta exposição, cria a composição musical "Amarelo Schwartz" cujas variações se desenvolvem nas perplexidades e potencialidades conceptuais que o próprio título potencia. A cor (que o título inventa e que a música traduz) vive na ambiguidade de um amarelo que é preto, estranho tipo de amarelo, ou onde, afinal, Schwartz não passa do apelido de uma cor, assim humanizada.

Julião Sarmento contraria aqui a forte hegemonia da manualidade na sua obra para apresentar uma monocromia que cita a pintura sem o ser. Um paralelepípedo negro de espessura suficiente para não se cingir à imagem de um quadrado, assumindo o carácter objectual de uma obra de parede. O título é, simplesmente a palavra "Preto", mas aqui a dimensão cromática que o aproxima da pintura é combinada com a presença do material de que é feito. "Corian Nocturne", material feito de pedra, material de construção de patente registada. Readymade não de um objecto, mas de um material, evocando a objectividade tectónica da construção.

Luísa Cunha apresenta uma obra sonora e sublinha o carácter objectual da presença da coluna de som que a transmite. Uma coluna de som cuja face donde o som se propaga é coberta de tecido vermelho, faz ouvir as palavras: "Senhora! Toda a gente sabe..." Fragmento de um diálogo (ou monólogo) onde o que se perde em sentido, se ganha num mistério que o vermelho qualifica e sublinha.

Manuel Gantes pinta uma vista aérea, uma paisagem densamente urbanizada. O título "Deserto Vermelho" parece contrariar a densidade urbana da imagem, ao mesmo tempo que densifica os tons avermelhados que a dominam. A ideia de deserto abre caminho para a antecipação do domínio total do vermelho que acabará certamente por engolir todo o espaço. 
Miguel Leal mostra, com "Stereo strobe", dois círculos num rectângulo preto que enquadram olhares sobre a paisagem, parcialmente sobrepostos como nos campos de visão de ambos os nossos olhos. Aqui a monocromia negra surge como parede entre nós e um mundo exterior ao qual acedemos, aqui em estereoscopia, dialéctica entre duas visões oculares extremamente próximas, não propriamente iguais.

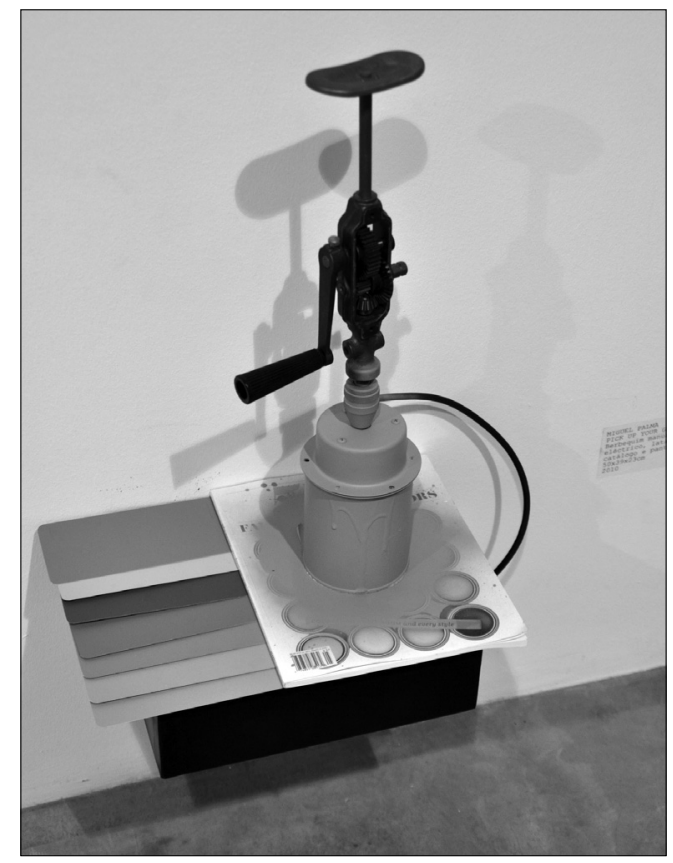

“Pick up your gray”, Miguel Palma, exposição MONO, 2010.

(C) Círculo de Artes Plásticas de Coimbra

Miguel Palma mostra "Pick up your gray", um objecto criado a partir da junção de um anacrónico berbequim manual mas paradoxalmente electrificado, cujo motor pousa sobre uma revista de decoração da qual sai uma sequência de cartões cinzentos como paleta de cores à escolha. Mas aqui, ironicamente, a cor é sempre o cinzento, sempre a mesma, uma cor que é uma não cor. Mas, ao mesmo tempo, mostra-nos que, afinal, existirá uma gama suficientemente grande de cinzentos para 
podermos associar a esta cor todo o sentido lúdico que, injustamente, não lhe atribuíamos.

Nuno Ramalho apresenta uma obra composta de dois documentos: uma cópia da carta que enviou para a sede do Partido Comunista Português, indagando nas relações simbólicas deste partido com a cor vermelha, e o talão dos CTT, prova da aceitação do registo da carta. $\mathrm{O}$ vermelho que se destaca no papel do registo, associado à imagem dos CTT, será certamente indiferente ao teor da carta enviada, como o será em relação a todas as cartas às quais talões como este comprovam o registo.

Paulo Mendes apresenta uma página da revista "Arte in América" onde um tubo de tinta acrílica amarela é o protagonista da publicidade à marca Winsor \& Newton. E encosta-lhe uma tela das mesmas dimensões da moldura com que a página foi emoldurada, tela pintada com o mesmo amarelo da publicidade. E, assim, cor, tinta, publicidade, obra de arte, obra que é de uma cor, cor que é a tinta que aquela marca produz,..., tudo em circuito fechado. Nesta objectivação tautológica, poderia ser aqui anulado todo o sentido evocativo que toda a obra de arte produz, mas em arte não há circuitos fechados, encontrando esta obra sentidos multiplicados no próprio processo de os parecer querer bloquear.

Pedro Amaral expõe uma tela quadrada que seria monocromaticamente amarela, não fosse a imagem sobre ela pintada de uma não tão inocente Branca de Neve (versão Disney) empunhando uma metralhadora e a legenda: "Fight lookism!" Nem o facto desta imagem visualmente pouco contrastar com o amarelo puro do fundo atenua a sua força iconográfica, gritante nos sinais contraditórios que nos dá. O slogan escrito na tela apela à luta contra o olhar, como se o olhar pudesse ser uma ideologia. Contraponto violento ao olhar que, se matar, só o fará metaforicamente. Imagem consciente do seu próprio absurdo mas que, como tudo em arte, na simultaneidade sentidos aparentemente contraditórios, se poderá levar também a sério, advertindo-nos para o perigo de deixarmos que se encare o voyeurismo como coisa passiva e inócua.

Pedro Calapez chama prosaicamente "12 camadas" à obra que apresenta. Múltiplas camadas de tinta em duas áreas que se vão justapondo na superfície e escondendo sucessivamente, deixando revelar a multiplicidade cromática nas margens que espreitam sob cada camada. $\mathrm{E}$, assim eficácia da forte visualidade desta pintura deve-se tanto às manchas de cor que se vêm como às que se adivinham. 
Pedro Pascoínho expõe um óleo sobre papel onde vemos um indivíduo que retira, sucessivamente, monocromias de um buraco quadrado na parede. $\mathrm{O}$ facto de estarem emolduradas leva-nos a crer de que se tratarão de pintura, de obras de arte. Como a representação pictórica congela um instante da acção, aquele indivíduo ficará ali para sempre, retirando do interior da parede sucessivas pinturas, variações cromáticas assim potencialmente infinitas.

Pedro Pousada usa fragmentos de objectos de plástico, madeira e cartão encontrados no lixo, escolhendo-os pela forma e pela cor, como que encontrando no lixo uma paleta de formas e cores à disposição. E constrói associações de formas que ganham, simultaneamente, as plasticidades da escultura e da pintura. O branco. O preto, o cinzento e o vermelho. Sobretudo o vermelho. Cor das revoluções? Continuidade com a atitude construtivista como se esta não tivesse sido interrompida nunca.

Pedro Tudela cria uma pintura/objecto, onde a presença de um alvo não deixa de nos fazer pensar nas pinturas alvo de Jasper Johns, na ideia da superfície pictórica como lugar de projecção da realidade com o será das suas cores. Um dos elementos da assemblage, dividindo em dois o objecto encontra-se assim em sintonia com o título: "And now in stereo" colocando aquela obra como mais uma de outras de um percurso. "Agora em stereo", consciente como Kandinsky do sentido sinestésico da composição pictórica.

Pedro Valdez Cardoso mostra-nos "Haunted" um objecto feito de pano preto, unificando na monocromia e na utilização de um mesmo material, uma casa de pássaros e uma cabeleira de tiras de pano que coloca sobre ela. Assim, o objecto ganha uma imagem antropomórfica. Casa assombrada, na perspectiva da casa de pássaros, assombração na perspectiva do lugar onde esta obra for exposta.

Pedro Zamith na sequência do seu trabalho entre a pintura e a ilustração, expõe aqui "Black, yellow, red, blue", um boneco em papier-maché policromado. As palavras que compõem o título e o nome de mais algumas cores surgem assim: "preto" no pé direito, "branco" no pé esquerdo, e "Black, Red, Yellow, Blue" em redor de uma cabeça aberta com o cérebro completamente exposto. A camisa-de-forças que envolve o tronco da personagem denuncia a contensão de uma dinâmica, eventualmente excessiva, associando as cores a uma expressividade explosiva para além de meros agentes de pura visualidade pictórica. 
Rita Castro Neves mostra a fotografia de um lápis de dupla valência cromática. Cada uma das extremidades está afiada para escrevermos, ou desenharmos, podendo escolher a extremidade do azul ou a do vermelho. Significativo é o facto do título se cingir a uma destas possibilidades. Ao atribuir à imagem o título "Azul”, a artista denuncia a possibilidade de um olhar que só um lado verá, ou a possibilidade de podermos, em cada momento, saber apenas o que escolhemos saber.

Rodrigo Oliveira mostra-nos uma pintura da série de pinturas que fez sobre tabuleiros de um jogo de Monopólio. Nas obras desta série, o artista parte da estrutura do tabuleiro, utilizando os espaços da grelha para os preencher de cor, em diferentes composições cromáticas. Para esta exposição optou pelo predomínio do vermelho, só colorindo com outras cores os rectângulos mais pequenos que, no jogo original, corresponderiam às cores dos bairros, alterando-as. O título "Square" aponta para uma essencialidade geométrica e a evocação de Mondrian é evidente, mas aqui a presença deste jogo resiste a qualquer intervenção plástica. De certa forma é como se os conceitos em jogo num jogo de Monopólio contaminassem o mundo da arte. Assistimos assim à perversão da essencialidade geométrica que Mondrian procurava como base estruturadora universal, tornando-se um jogo de Monopólio mas, neste caso, um monopólio num território vermelho, o que faz gerar novas ambiguidades nos sinais contraditórios que parece transmitir.

Rui Ferreira apresenta uma tela pintada de um amarelo pálido cuja tinta começa a levantar como se estivesse a mudar a pele, deixando ver pequenos pedaços de tinta vermelha de uma primeira camada de cor. "Pele" é mesmo o título da obra, estreitando a relação entre o jogo conceptual e a própria técnica usada. A tradução da cor enquanto pele de uma obra de arte, ao mesmo tempo a humaniza e nos sugere a presença de todo um universo para além da superfície de uma tela, ou melhor, que residirá debaixo da sua pele.

Sofia Leitão, com "Black hair" cria um objecto de parede que, mais do que reproduzir um cabelo ou um penteado, explora as possibilidades compositivas dos cabelos e dos penteados se estes se libertassem das cabeças. E fá-lo todo de missangas pretas cuja cintilação confere uma plasticidade luxuriante ao objecto, quase como se de uma jóia se tratasse, atenuando assim a repulsa que associamos aos cabelos quando estes já não pertencem às cabeças. 
Susana Mendes Silva cria a peça “Arco-íris". Seis linhas de texto na parede onde poderíamos ler uma lista de doenças com nomes associados a cores como albinisno, pano branco, peste negra, febre amarela, escarlatina,... podendo colocar auscultadores e optar pela versão sonora das palavras ditas pela voz da artista. Da plasticidade amável que associamos às cores, sobretudo num contexto pictórico, a artista vem aqui lembrar que o seu campo de expressão poderá abarcar outras realidades. Aqui cores que passam da condição de imagem para a objectividade crua das doenças, muitas vezes de terríveis consequências.

Valdemar Santos expõe uma pequena bandeira portuguesa, pintura sobre tela, a preto e branco. A tela colada na parede, sem grade, numa disposição ondulante, como uma bandeira. É uma bandeira pintada numa tela mas, assim, também é uma bandeira de tela no curto-circuito entre a representação e o objecto representado. Além disso é uma bandeira a preto e branco. Como seria uma fotografia a preto e branco. A imagem desta tela/bandeira não se produz na visualidade. Pelo simples facto de conhecermos as cores da bandeira nacional, percepcionamo-las sempre, mesmo que estejam ali, assim, cores pintadas a preto e branco.

Pedro cabral Santo apresenta uma pequena pintura sobre papel, feita de quadrados de diferentes cores numa grelha onde pulsam as relações cromáticas, num olhar que nunca consegue fixar-se num só lugar. Sobre 3 dos quadrados, com tinta preta, impressões digitais do artista. 3 como as letras $\mathrm{ABC}$ do título: "Impressão $\mathrm{ABC}$ (ao grupo cores)". E esta obra, única que faz alusão ao grupo que nesta exposição é evocado, retoma a atitude de Armando Azevedo na última acta do "grupo CORES", ao assumir como individual o espaço do colectivo. Não por Pedro Cabral Santo conhecer a existência dessa acta, porque a desconhecia por completo. Mas, aqui, como sendo um sintoma do facto de não existirem em absoluto campos exclusivos de cada artista. $\mathrm{E}$, na forma como cada um inclui os outros, reside aqui a incontornável dimensão estética da arte.

Na relação entre o artista e os outros, nomeadamente entre o artista e a urbe, é particularmente significante a forma como, em 1976, em Coimbra, ano das primeiras Eleições Livres, Armando Azevedo anuncia uma sua exposição no CAPC. 


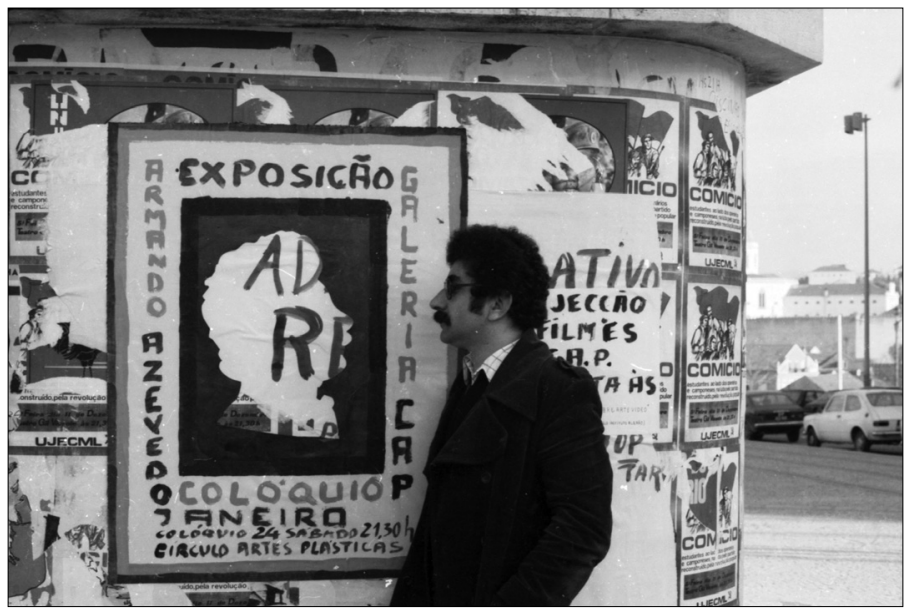

Cartazes Armando Azevedo 1976. (C) Armando Azevedo

Cola cartazes pelas ruas da cidade. Texto escrito à mão, o artista anuncia pelo seu próprio punho as datas da sua exposição. Centrada no cartaz, recorta a silhueta do perfil da sua cabeça. Perfil que vai ficando preenchido pelas imagens de propaganda que cobriam as paredes.

“... espalhei-os pelas paredes da cidade, que na altura estavam saturadas de publicidade política, religiosa, comercial ... Conforme o lugar onde colava os cartazes, a minha cabeça preenchia-se da respectiva publicidade.

"No meio da amálgama da propaganda nas paredes, vemos a imagem da nossa cabeça lá reflectida"

A escrita colectivizante (com palavras e imagem massificantes) a moldar a cabeça dum indivíduo (moldando-lhe o pensamento, o gosto, o olhar ...)

Exemplo de uma escrita individual jogando sobre diversos tipos de escritas colectivas (e, inclusive, colectivizantes)."

Ao sugerir a ideia de que "No meio da amálgama da propaganda nas paredes" se verá "a imagem da nossa cabeça lá reflectida" Armando Azevedo vai para além da especificidade desta acção que realizou em 1976. Revela sobretudo a sua dimensão simbólica, projectando para os outros e para cada indivíduo em particular, a ideia de uma identidade projectada no espaço urbano, sobretudo no ruído da simultaneidade de 
sinais que a urbe nos transmite. Não um espaço urbano higienizado, mas como lugar de todas as contaminações. Num rosto que se apresenta e se oferece comunicando-se como um cartaz. E, ao mesmo tempo, a imagem que transmite de si e que entende ser a da sua identidade é (e são, numa pluralidade tornada singular) as imagens da própria urbe, devolvida a si própria, enquanto matéria de que as coisas são feitas, de que os indivíduos são feitos. 